\title{
Prostaglandin EP2 receptor: Novel therapeutic target for human cancers (Review)
}

\author{
XIAOTING SUN and QI LI \\ Department of Medical Oncology and Cancer Institute of Integrative Medicine, Shuguang Hospital, \\ Shanghai University of Traditional Chinese Medicine, Shanghai 201203, P.R. China
}

Received January 25, 2018; Accepted June 21, 2018

DOI: $10.3892 /$ ijmm.2018.3744

\begin{abstract}
Prostaglandin E2 (PGE2) receptor 2 subtype (EP2), which is a metabolite of arachidonic acid that binds with and regulates cellular responses to PGE2, is associated with numerous physiological and pathological events in a wide range of tissues. As a stimulatory $\mathrm{G}$ protein-coupled receptor, PGE2-induced EP2 activation can activate adenylate cyclase, leading to increased cytoplasmic cAMP levels and activation of protein kinase A. The EP2 receptor can also activate the glycogen synthase kinase $3 \beta$ and $\beta$-catenin pathways. The present study aimed to review the roles of the EP2 receptor in tumor development, including immunity, chronic inflammation, angiogenesis, metastasis and multidrug resistance. Furthermore, the involvement of the EP2 receptor signaling pathway in cancer was discussed. Understanding the role and mechanisms of action of the EP2 receptor, and its importance in targeted therapy, may help identify novel methods to improve management of numerous types of cancer.
\end{abstract}

\section{Contents}

1. Introduction

2. Structure of the EP2 receptor

3. Biological activity of the EP2 receptor

4. Regulating the function of the EP2 receptor in cancer

5. Involvement of EP2 receptor signaling pathways in cancer

6. Regulation of EP2 receptor signaling by genetic engineering

7. Development of agonist, antagonists and targeted drugs for EP2

8. Conclusions and prospects

Correspondence to: Professor Qi Li, Department of Medical Oncology and Cancer Institute of Integrative Medicine, Shuguang Hospital, Shanghai University of Traditional Chinese Medicine, 528 Zhangheng Road, Shanghai 201203, P.R. China

E-mail: 1zwf@hotmail.com

Key words: EP2, mechanism, cancer, invasion, inflammation

\section{Introduction}

Prostaglandin E2 (PGE2) receptor 2 subtype (EP2) is a G protein-coupled plasma membrane receptor for PGE2, which acts through numerous signaling pathways to regulate various physiological functions, including tumor occurrence, invasion and metastasis, angiogenesis, chronic inflammation, tumor immunity and cell apoptosis (1). Recently, various studies have focused on identifying the specific EP2 receptors and signaling pathways that regulate the pleiotropic activities of the cyclooxygenase-2 (COX-2)/PGE2/EP2 pathway (2-5).

Over the past 10 years, COX-2 and its prostaglandin products have attracted increasing attention due to their important roles in the progression of tumors of the lung, head and neck, prostate, colon, ovary, chest and liver (2,6-8). However, inhibition of COX-2 using non-steroidal anti-inflammatory drugs (NSAIDs) and specific COX-2 inhibitors is associated with various side effects, including gastric ulcers and myocardial infarction (9), which have limited the use of these drugs (10). As a primary prostanoid derived from COX-2, PGE2 can also promote the activities of tumor cells (11); therefore, inhibition of the biological activities of PGE2 at different levels may maintain the anticancer properties of COX-2 inhibition and also help prevent side effects (12). Among four pharmacologically different $G$ protein-coupled plasma membrane receptors of PGE2, the EP2 subunit is an important mediator of numerous physiological and pathological processes, and may be the most useful targeted receptor in anticancer treatment (13). The present review aimed to highlight the potential role of EP2 in cancer (Fig. 1).

\section{Structure of the EP2 receptor}

EP2 (53 kDa) (14) is a PGE2 receptor encoded by the human PTGER2 gene. The PTGER2 gene contains two introns and three exons, and is located on human chromosome 14 at position p22.1 (14q22.1) (15).

The human EP2 receptor consists of 358 amino acids, whereas the mouse EP2 receptor consists of 632 amino acids (16). It belongs to the family of $\mathrm{G}$ protein-coupled receptors (GPCRs), which constitute a large protein family of receptors that detect molecules outside the cell and activate internal cellular responses (17). EP2 is an integral membrane protein that has an extracellular N-terminus and an intracellular C-terminus $(18,19)$. It has seven transmembrane (7-TM) 
$\alpha$-helices (TM-1 to TM-7) connected by three intracellular (IL-1 to IL-3) and three extracellular (EL-1 to EL-3) loops (20). The $\mathrm{EP} 2$ is bound to a heterotrimeric $\mathrm{G}$ protein complex consisting of the $\mathrm{G}$ stimulatory $\left(\mathrm{G}_{\mathrm{sub}}\right) \alpha$ and the tightly associated $\mathrm{G}_{\beta \gamma}$ subunits $(21,22)$. Binding of an agonist to EP2 results in activation of the $\mathrm{G}_{\mathrm{s}} \alpha$ subunit, which regulates the cAMP-dependent pathway by stimulating the production of cAMP from ATP (23) (Fig. 2). Both EP2 and EP4 are bound to $\mathrm{G}_{\mathrm{s}} \alpha$ subunits (24).

\section{Biological activity of the EP2 receptor}

The expression of EP2 receptor EP2 is widely distributed in humans (25). The EP2 protein is expressed in the human small intestine, lung, media of arteries and arterioles of the kidney, thymus, uterus and cerebral cortex (26). In addition, its mRNA is widely expressed in fibroblasts, aorta, the corpus cavernosum of the penis and articular cartilage, among others (27-29) (Fig. 3). In rats, EP2 receptor protein and/or mRNA have been detected in the lung, spleen, intestine, skin, kidney, liver, long bones, and rather extensively throughout the brain and other parts of the central nervous system (30). Therefore, the EP2 receptor appears to serve a key role in biological development.

Desensitization. Activated GPCRs can be phosphorylated by G protein-coupled receptor kinases (GRKs) (31), which modifies $G$ protein-dependent signaling by initiating receptor desensitization, internalization and resensitization (32). However, EP2 differs from all other prostaglandin receptors in that it does not undergo homologous desensitization (33). When EP4 is expressed in Chinese hamster ovary cells, EP4 receptors are found to undergo rapid PGE2-induced desensitization, which is not observed with EP2 receptors (32). Due to its failure to become desensitized, EP2 can act over more prolonged periods of time compared with other prostaglandin receptors and, therefore, may be able to contribute to more delayed and chronic phases of cellular and tissue responses (34).

Positive feedback regulation. PGE2 signaling through EP2 can in turn boost expression of COX-2 in polyp tissues (35), and it has been suggested that EP2 may regulate phosphorylated (p)-phosphatidylinositol-4,5-bisphosphate 3-kinase (PI3K), p-protein kinase B (Akt) and p-glycogen synthase kinase $3 \beta$ (GSK-3 $\beta$ ) expression, and increase nuclear translocation of $\beta$-catenin in LoVo cancer cells (36). The levels of the cofactors lymphoid enhancer-binding factor-1 (LEF-1) and transcription factor 4 (TCF-4) have also been reported to be upregulated by EP2 in the nucleus, resulting in upregulation of COX-2 expression (37). Using genetically engineered animal models lacking EP2, or using EP2 antagonists in animals and animal and human tissues, it has been reported that a lack of EP2 may downregulate the expression of p-PI3K, p-Akt and p-GSK-3 $\beta$, and reduce the levels of $\beta$-catenin and cofactors LEF- 1 and TCF-4 $(5,38,39)$. Therefore, inhibition of EP2 may reduce the proliferation and invasion of cancer cells.

\section{Regulating the function of the EP2 receptor in cancer}

The function of the EP2 receptor. Numerous studies have demonstrated that EP2 is abnormally expressed in cancer, including colon, prostate, liver and breast cancer (5,40-43) (Fig. 4). Furthermore, EP2 is associated with poor survival in chronic obstructive pulmonary disease (Fig. 5). The aberrant expression of EP2 has been found to be closely associated with factors associated with cancer development, including chronic inflammation, immunoregulation, angiogenesis, metastasis and multidrug resistance.

EP2 induces chronic inflammation. It was recently demonstrated that inflammation serves a key role in cancer, and $\sim 60 \%$ of cancers are associated with inflammation (44). The inflammatory response may create a partial microenvironment that promotes alterations in the genome and stimulates the formation of tumors. Some tumor cells release cytokines and chemotactic factors to attract monocytes and macrophages (45). The infiltrating macrophages in turn secrete growth factors to promote tumor progression, recruit secondary leukocytes, and enhance and maintain the interaction between inflammatory and tumor cells (46).

As a main inflammatory mediator derived from COX-2, PGE2 can induce several proinflammatory factors, including cytokines, chemotactic factors, inducible nitric oxide synthase (iNOS) and even COX-2 (47). These factors can promote cell proliferation, survival, angiogenesis, invasion, migration and metabolism (48). In addition, EP2 activation can significantly induce the expression of proinflammatory factors, such as interleukin (IL)- $1 \beta$ and IL-6 in tumor cells $(42,49)$. IL- $1 \beta$ can promote tumor growth, invasion and angiogenesis (50). Under normal conditions, IL-6 levels are increased in patients with several types of cancer, including prostate, colon, breast and ovarian cancer (51). The PGE signals initiated by EP2 or EP4 can exacerbate symptoms of inflammation by increasing the expression levels of IL-23, and decreasing the levels of IL-12 and IL-27 (52). PGE, together with IL-1 $\beta$ and IL-23, promotes the differentiation and cytokine expression of $\mathrm{T}$ helper (Th)17 cells (53). Recent research has revealed that hepatic stellate cells increase the numbers of Th17 cells and regulatory $\mathrm{T}$ cells via the PGE2/EP2 pathway (54). Hepatic Th17 and regulatory $\mathrm{T}$ cell numbers are also increased in patients with advanced-stage hepatitis B virus-associated liver fibrosis, which potentially leads to hepatocellular carcinoma $(55,56)$. In addition, PGE signals can affect the skin microenvironment through enhancing blood flow by regulating ultraviolet (UV)-induced acute skin inflammation $(57,58)$. As a result, small-molecule antagonists of EP2 can mitigate chronic inflammation in tumor tissues to provide an anti-inflammatory mechanism for the treatment of cancer (56).

In colon tumors, EP2 is expressed by infiltrating neutrophils and tumor-associated fibroblasts in the stroma (39). The expression levels of tumor necrosis factor- $\alpha$ (TNF- $\alpha$ ), IL-6, chemokine (C-X-C motif) ligand 1 (CXCL1), COX-2, and other proinflammatory genes acting synergistically with TNF- $\alpha$, are upregulated by EP2 $(42,49)$. These results indicate that EP2 in neutrophils and tumor-associated fibroblasts promotes colon tumorigenesis by exerting a proinflammatory effect and regulating the tumor microenvironment $(59,60)$.

EP2 contributes to cancer immunotherapy resistance. Since EP2 has an important role in the differentiation of DCs (3), and it also has an important role in the function and 


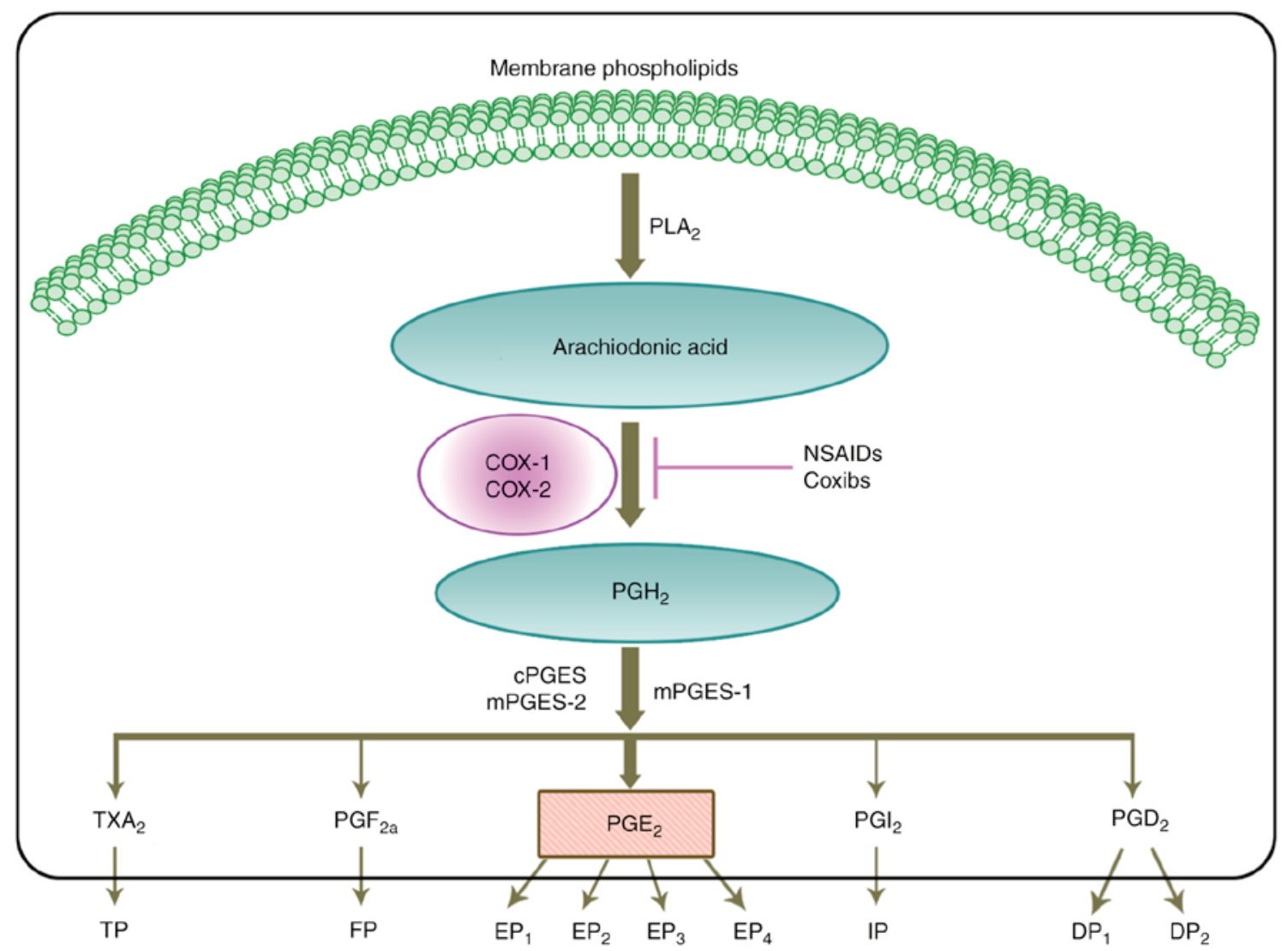

Figure 1. Biosynthesis of the prostaglandin EP2 receptor. Firstly, with action of PLA2 family members, arachidonic acid is released from cell membranes and converted to PGH2 through the activity of COX enzymes. PGH2 is rapidly converted to TXA2, PGF2 $\alpha$, PGE2, PGI2 and PGD2 by one of three PGE2 synthases: cPGES, mPGES-1 or mPGES-2. PGE2 signals through four G-protein coupled receptors, namely EP1, EP2, EP3 and EP4. NSAIDs and Coxibs can block the activity of COX enzymes, and inhibit the synthases of PGE2. Therefore, they may suppress the pro-tumorigenic function of PGE2. Alternatively, they may also suppress the activity of PGE2 by blocking EP2. c, cytoplasmic; COX, cyclooxygenase; Coxibs, COX inhibitors; DP, PGD2 receptor; EP, PGE2 receptor; FP, PGF receptor; IP, PGI2 receptor; m, microsomal; NSAIDs, non-steroidal anti-inflammatory drugs; PG, prostaglandin; PGES, PGE2 synthase; PLA2, phospholipase A2; TP, thromboxane receptor; TXA2, thromboxane 2.

immunoregulation of PGE2 suppression; therefore, the elimination of EP2 receptors can suppress the growth of tumors and prolong survival (7). PGE2 contributes to immune evasion and cancer immunotherapy resistance by suppressing the function of macrophages, neutrophils and Th1 cells. PGE2 also markedly inhibits the production of Th1 cytokines, including interferon- $\gamma$ (IFN- $\gamma$ ), TNF- $\alpha$ and IL-2 (61). The immunoregulation of PGE2 is initiated through EP2 receptor signaling. Activation of EP2 can downregulate the expression of IFN- $\gamma$ and TNF- $\alpha$ by immune cells, such as natural killer T cells, neutrophilic granulocytes and macrophages (62), and adversely affects the immunocompetence of these immune cells (47).

The signals initiated by the EP2 receptors can be transduced by the same $\mathrm{G}_{\mathrm{s}} \alpha$ stimulating protein and the concentration of cAMP in cells is increased by activation of EP2 (63). Cluster of differentiation (CD) $4^{+}$Th cells are a key effector in the adaptive immune system to control cancer (64) and the increase in cAMP is associated with a decrease in Th1 cells and IFN- $\gamma$ (65). In addition, PGE2 can suppress the activities of natural killer cells and cytotoxic $\mathrm{T}$ lymphocytes, which are part of antitumor immunity (66).

Apart from the direct suppression of immune cell activities, EP2 signaling can promote the development of regulatory $\mathrm{T}$ cells, which are efficient inhibitors of the immune system and can suppress the activity of numerous immune cells,

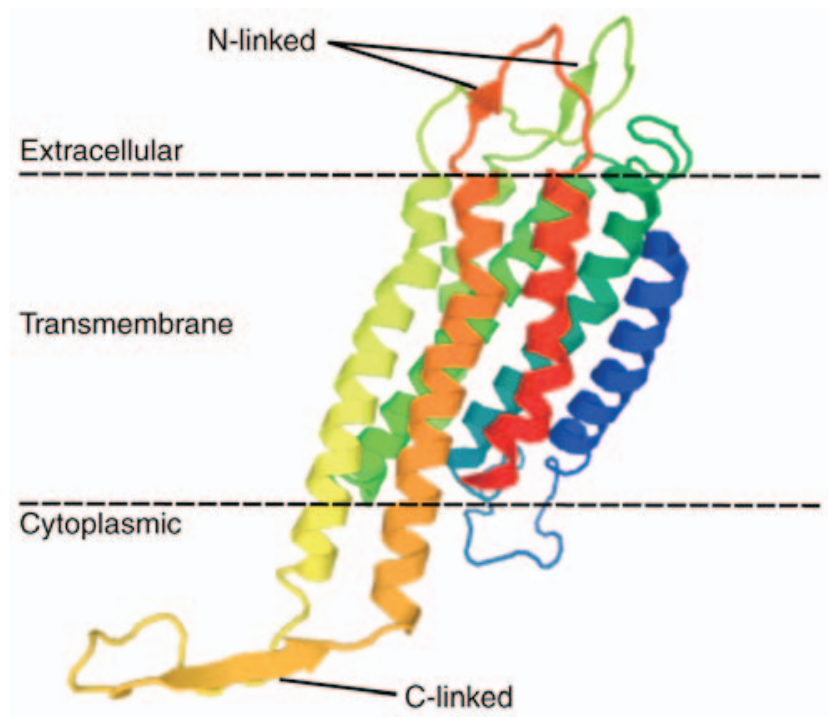

Figure 2. Structure of the EP2 receptor. The human EP2 receptor belongs to the family of $\mathrm{G}$ protein-coupled receptors. EP, prostaglandin E2 receptor 2 subtype.

including DCs (67). DCs have a key role in the initiation of the tumor-specific immune response (52). The signals of EP2 


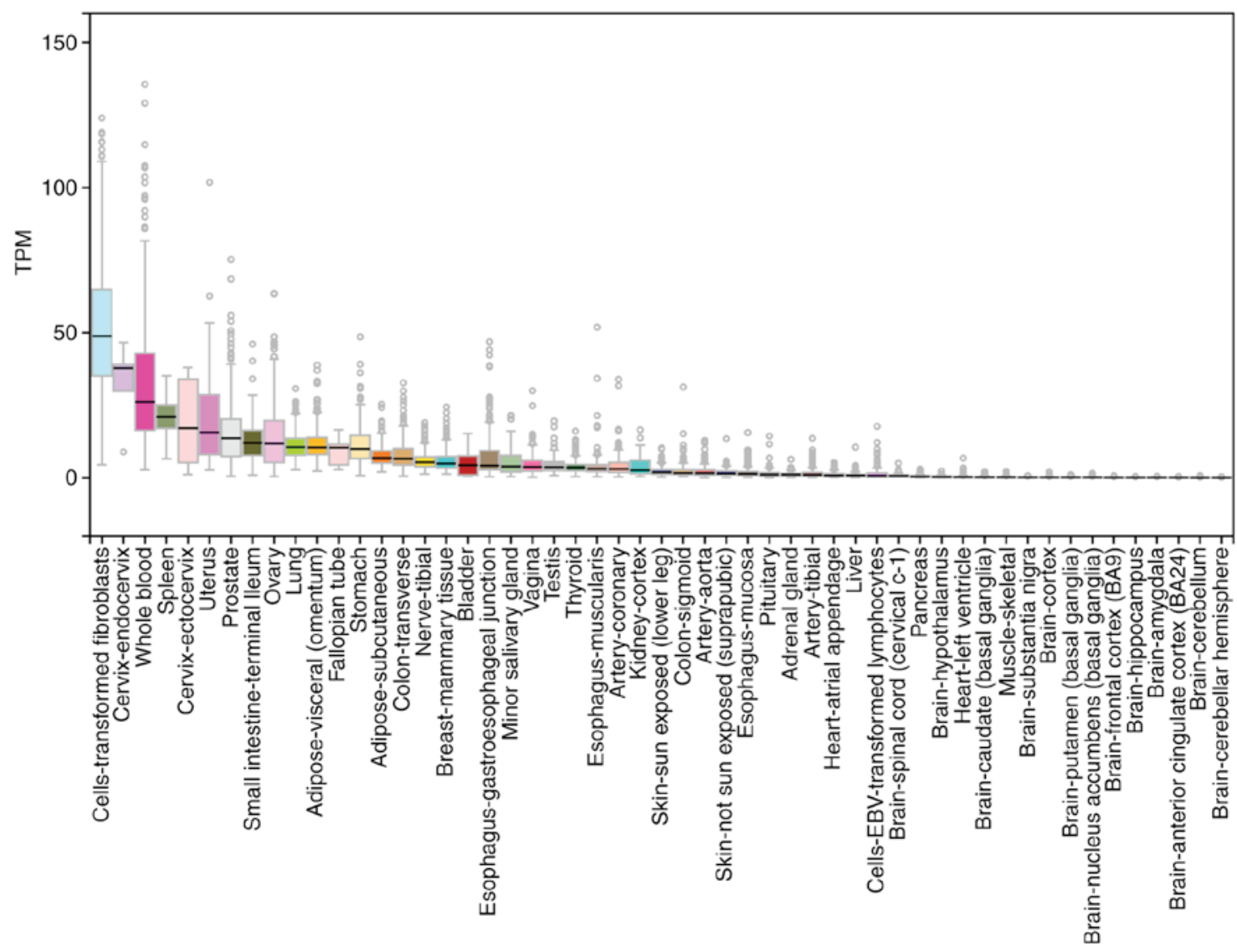

Figure 3. Expression of EP2 in humans. EP2 is expressed in several types of human cells, including cells of the small intestine, lung, media of arteries and arterioles of the kidney, thymus, uterus, cerebral cortex, corpus striatum, hippocampus, corneal epithelium, corneal choriocapillaries, myometrium, eosinophils, sclera, articular cartilage, penile corpus cavernosum and airway smooth muscle cells. Data source: GTEx Analysis Release V7 (dbGaP Accession phs000424. v7.p2). EP, prostaglandin E2 receptor 2 subtype.

(and EP4) not only block DC activity, but can also block the generation of DCs, resulting in development of the immunosuppression of myeloid-derived suppressor cells (68).

Knockout of the EP2 receptor can reduce tumor progression and prolong the survival of mice injected with MC26 or Lewis lung carcinoma cells (69). This mechanism appears to be associated with the failure of PGE2 to suppress differentiation of DCs, leading to induction of the antitumor cytotoxic T-lymphocyte response (70). In a mixed lymphocyte model of the cellular immune response, it was reported that EP2 and EP4 could regulate the functions of antigens, indicating that EP2 receptors can directly inhibit immune cell proliferation (71).

EP2 increases angiogenesis. EP2 can induce angiogenesis in cancer, whereas the deletion of EP2 receptors can downregulate the expression of angiogenic factors, including vascular endothelial growth factor (VEGF), and inhibit tumor angiogenesis (72). Apart from VEGF induction by EP2 activation, EP2 signaling in endothelial cells can regulate the activity and survival of endothelial cells and promote tumor angiogenesis in vivo (73). PGE2 signaling triggers hyperplasia of the mammary gland and regulates VEGF induction in breast tumors in mice (53). In addition, EP2 signaling can directly regulate tumor angiogenesis and survival by enhancing the activity of epithelial cells $(1,74)$. It can also regulate hypertrophy and tumor invasion as a response to UV stimulation and induce the growth of skin tumors (57). In addition, PGE2 facilitates tube formation through EP2 signaling (23), indicating the involvement of EP2 in luteal angiogenesis and the progression of ovarian cancer (75).

EP2 promotes tumor invasion and metastasis. In addition to its association with angiogenesis and immune suppression in cancer, a recent study demonstrated that EP2 receptor activation by PGE2 significantly enhances hepatocellular carcinoma cell invasion and migration by upregulating the expression levels of Snail (76). It has also been demonstrated that treatment with various concentrations of prostaglandin promotes the migratory ability of human LoVo colon cancer cells via the EP2 receptor (40).

The PI3K signaling pathway has a key role in the regulation of cell proliferation, differentiation, migration and trafficking (77). The PI3K/Akt cell survival pathway has been revealed to be upregulated by EP2 and EP4 activation $(78,79)$, thereby upregulating the level of matrix metalloproteinases, which has been observed in several types of human cancer and regulates the efficacy of various therapies (5). In breast cancer, EP2 receptors are also associated with metabolism, which may alter the response of cells to transforming growth factor- $\beta$ (TGF- $\beta$ ), which can maintain the balance of tissues by inducing cell cycle arrest, differentiation and apoptosis (80). 


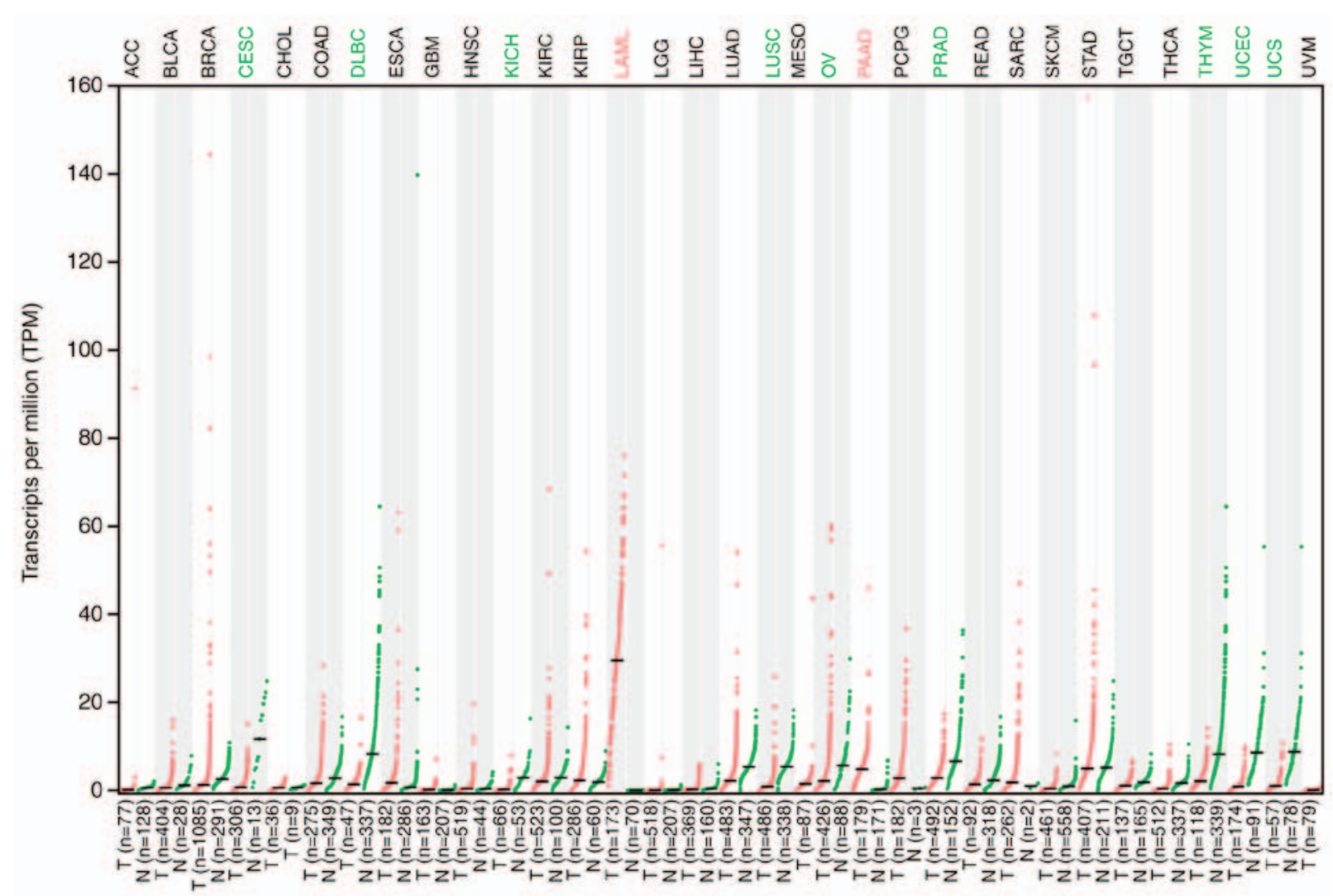

Figure 4. Prostaglandin E2 receptor 2 subtype expression profile across all tumor samples and paired normal tissues (dot plot). Each dot represents expression of samples. Data source: The RNA-Seq datasets GEPIA, Ensembl ID: ENSG00000125384.6 (http://gepia.cancer-pku.cn/) (115).

However, during tumorigenesis, genetic and epigenetic events convert TGF- $\beta$ from a tumor suppressor to a promoter of cell growth, invasion and metastasis (16). The altered response to TGF- $\beta$ may be attributed to the suppression of TGF- $\beta$-induced Smad2/3 nuclear localization and signaling by PGE2, followed by uncoupling TGF- $\beta$ from activating Smad3 (16).

In addition, EP2 has been reported to regulate metastasis via downregulation of solute carrier family 19 member 3 in triple-negative breast cancer (81). In addition, EP2 ablation suppresses skin tumor development by limiting angiogenesis and promoting apoptosis (82-84), whereas the overexpression of EP2 accelerates skin tumor development. EP2 also accelerates the invasion of prostate tumor cells, which is inhibited by the EP2 antagonist, TG4-155 (85). In laryngeal carcinoma, upregulated EP2 expression has been detected in highly aggressive tumors, which are identified by deeper invasion of the submucosa or cartilage (86).

EP2 promotes multidrug resistance (MDR) in cancer. Epidermal grow th factor receptor (EGFR) is alsoinvolved in the pathogenesis and development of various types of cancer (87). The activation of EGFR accelerates the uncontrolled proliferation and metabolism of cancer cells (88), whereas an inhibitor of EGFR can be used to treat non-small cell lung cancer, and pancreatic, breast and colon cancer (89). Despite the initial dynamic response to these inhibitors, the majority of patients ultimately develop resistance to therapy (90). It has been reported that PGE2 results in tyrosine kinase inhibitor resistance in some patients with cancer through EP2 transactivation of EGFR (91). Although the potential underlying mechanism

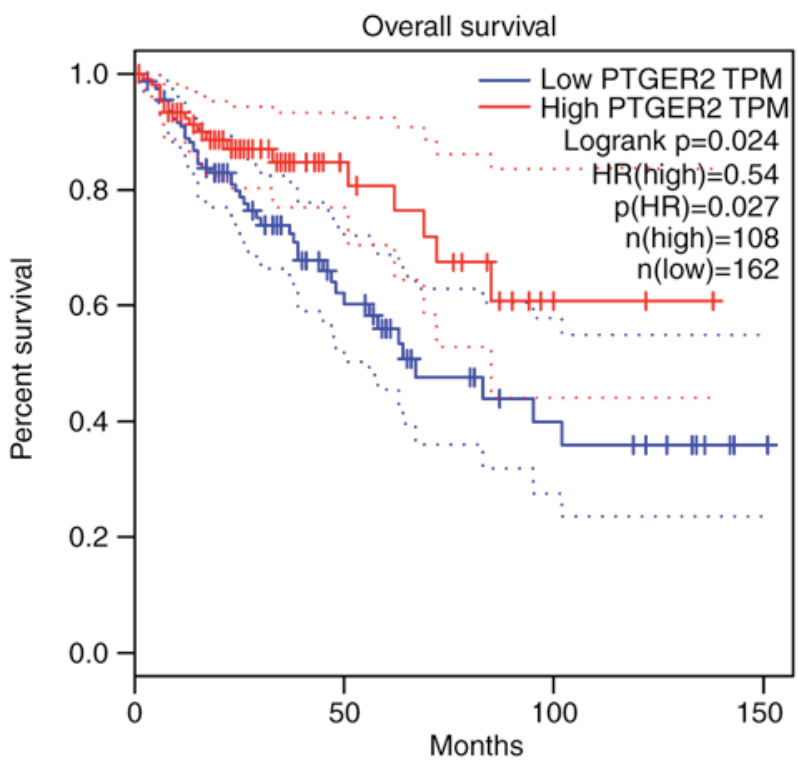

Figure 5. EP2 is associated with poor survival in chronic obstructive pulmonary disease. EP2, prostaglandin E2 receptor 2 subtype; TGER2, EP2 gene. Data source: The RNA-Seq datasets GEPIA (http://gepia. cancer-pku.cn/) (115).

remains unclear, accumulating evidence suggests that PGE2 is associated with MDR in cancer (92). However, clinical trials combining specific COX-2 inhibitors, including celecoxib and aproxicoxib, with EGFR inhibitors, such as erlotinib, have not produced promising results. By contrast, they result in toxicity 
in a proportion of patients $(91,93)$. Therefore, more studies are required to elucidate how to use the EP2 receptor as a target to attenuate MDR in cancer.

\section{Involvement of EP2 receptor signaling pathways in cancer}

EP2 receptor signaling pathways. An increasing number of studies has demonstrated that EP2 regulates cancer development various signaling pathways (Fig. 6).

EP2 receptors mediate second messenger signaling. As a Gs-coupled receptor, EP2 activation by PGE2 can activate adenylate cyclase, thus resulting in an increase in cAMP levels and protein kinase A (PKA) activation. In response to cAMP binding, PKA activates and phosphorylates downstream transcription factors, including cAMP response element-binding protein (CREB), which regulate a wide range of biological processes. In cells expressing EP2, $1 \mu \mathrm{M}$ PGE272 is activated to form cAMP (94). In addition, aromatase-dependent estrogen synthesis is associated with hormone-dependent breast cancer (81), and EP2 can regulate the cAMP/PKA/CREB pathway, in turn regulating cytochrome P450 aromatase (75).

$E P 2-G_{s}$-axin-pathway. EP2 can also activate the GSK $3 \beta$ and $\beta$-catenin pathways, in turn increasing the transcription of several genes associated with cancer, including c-myc, cyclin D1 and VEGF. When PGE2 activates EP2, a $\mathrm{G}_{\mathrm{s}}$ subunit directly binds with a structural region, also referred to as the regulator of $\mathrm{G}$ protein signaling (RGS). As a consequence, it can promote the release of GSK-3 $\beta$ (95). Furthermore, EP2 receptors activate $\beta / \gamma$ subunits to release Gas subunits and stimulate Akt by PI3K, resulting in the phosphorylation and inactivation of GSK-3 $\beta$ (96). However, this inactivation can lead to the accumulation of $\beta$-catenin in the cytoplasm and migration to the cell nucleus, where it can interact with TCF and LEF to activate genetic transcription promoting tumor growth (57).

Castellone et al (39) reported that EP2 receptors are involved in the PI3K/Akt and axin/ $\beta$-catenin pathways activating colon tumor growth. It was revealed that when the Gas subunit was bound to the RGS domain, free G protein $\beta / \gamma$ subunits could stimulate PI3K and Akt to activate $\beta$-catenin and proliferation of DLD-1 cells, resulting in the mutation of adenomatous polyposis coli (APC) genes. It appears that GPCR signaling pathways can interact with APC- $\beta$-catenin-TCF. Numerous proteins, including Dsh, axin, GSK-3 $\beta$ and APC, are involved in the Wnt pathway and can interact with $\mathrm{G}$ proteins (39).

Crosstalk with other signaling pathways. It has been demonstrated that EP2 can activate $\mathrm{G}$ protein-independent signaling pathways through the formation of EP2 and $\beta$-arrestin complexes. $\beta$-arrestin serves as a regulator that switches signals to $G$ protein-independent signaling pathways (97). It was recently reported that EP2 can regulate $\beta$-arrestin signaling to initiate the PI3K, Akt, Src, extracellular signal-regulated kinase (ERK), c-Jun N-terminal kinase (JNK) and EGFR pathways; therefore, it may have an important role in the proliferation and migration of cells. Through PI3K and Akt, rather than through conventional cAMP signaling, EP2 can inhibit the occurrence of tumor immunity (98).

Previous studies have demonstrated that the crosstalk between EP2 and EGF pathways increases the complexity of the EP receptor pathways $(97,98)$. EGFR is located on the surface of cells and can activate EGF and TGF- $\alpha$ through binding with ligands. EP receptors promote the transactivation of EGFR and involve activation of c-Src genes. Phosphorylation can directly or indirectly activate EGFR and EGFR ligands, in order to stimulate the EGFR signaling network. Activation of EGFR can activate several signal transduction pathways, including mitogen-activated protein kinase, PI3K/Akt, signal transducer and activator of transcription and phospholipase C, thus leading to the proliferation, differentiation, migration and survival of cells. iNOS, ERK1/2 and EP2 can be activated through indirect activation of EGFR to promote the growth of squamous cell tumors (93). In addition, $\beta$-arrestin can cause the phosphorylation of JNK, upregulate profilin 1, increase the expression of f-actin, and promote the migration and proliferation of tumor cells (99).

In conclusion, these signaling routes in the nucleus promote the expression of genes associated with the growth, survival, immune evasion, angiogenesis, infiltration and metabolism of cancer cells.

\section{Regulation of EP2 receptor signaling by genetic engineering}

Genetic ablation strategies and biochemistry studies provide tools for elucidating EP2 signaling. In addition, studies in EP2-knockout mice suggest that EP2 signaling has a key role in cancer $(59,60)$. A recent study on EP2-null mice undergoing a two-stage chemical carcinogenesis protocol revealed that EP2-null mice may develop fewer tumors (50\%) and smaller tumors compared with in wide-type mice. In addition, macrophage infiltration was decreased, as was the expression of IL-1 $\alpha$ in the epidermis, and angiogenesis. Mice deficient in EP2 receptors also exhibit low incidence rates of lung, skin and breast cancer (59).

Gene knockout strategies have been used to study the potential functions of EP2 in colon cancer. In a mouse model of familial adenomatous polyposis, a genetic ablation in EP2 resulted in an $\sim 100 \%$ incidence of colon cancer. Although genetic ablation of the EP2 receptor does not affect the formation of aberrant crypts, it affects the formation of polyps and tumor angiogenesis through Wnt/ $\beta$-catenin pathway (59). In addition, genetic ablation of EP2 reduces the size and number of intestinal polyps in APC1309 mice, simulating the gene disruption or inhibition of COX-2 in the same model. Similar to Min mice, APCD716 mice also harbored a mutation in the same tumor suppression gene, which may result in the development of colon cancer (39).

In order to investigate the major gene expression alterations in tumor tissues, in a previous study, EP2-knockout mice were implanted with $\mathrm{EP} 2^{+/+}$epithelial-like tumors. As a result, tumor growth, acute inflammation and IL-6 expression were suppressed in EP2-knockout mice. The expression of several genes, including long non-coding RNAs, was also decreased in tumors from the EP2-knockout mice (2). 


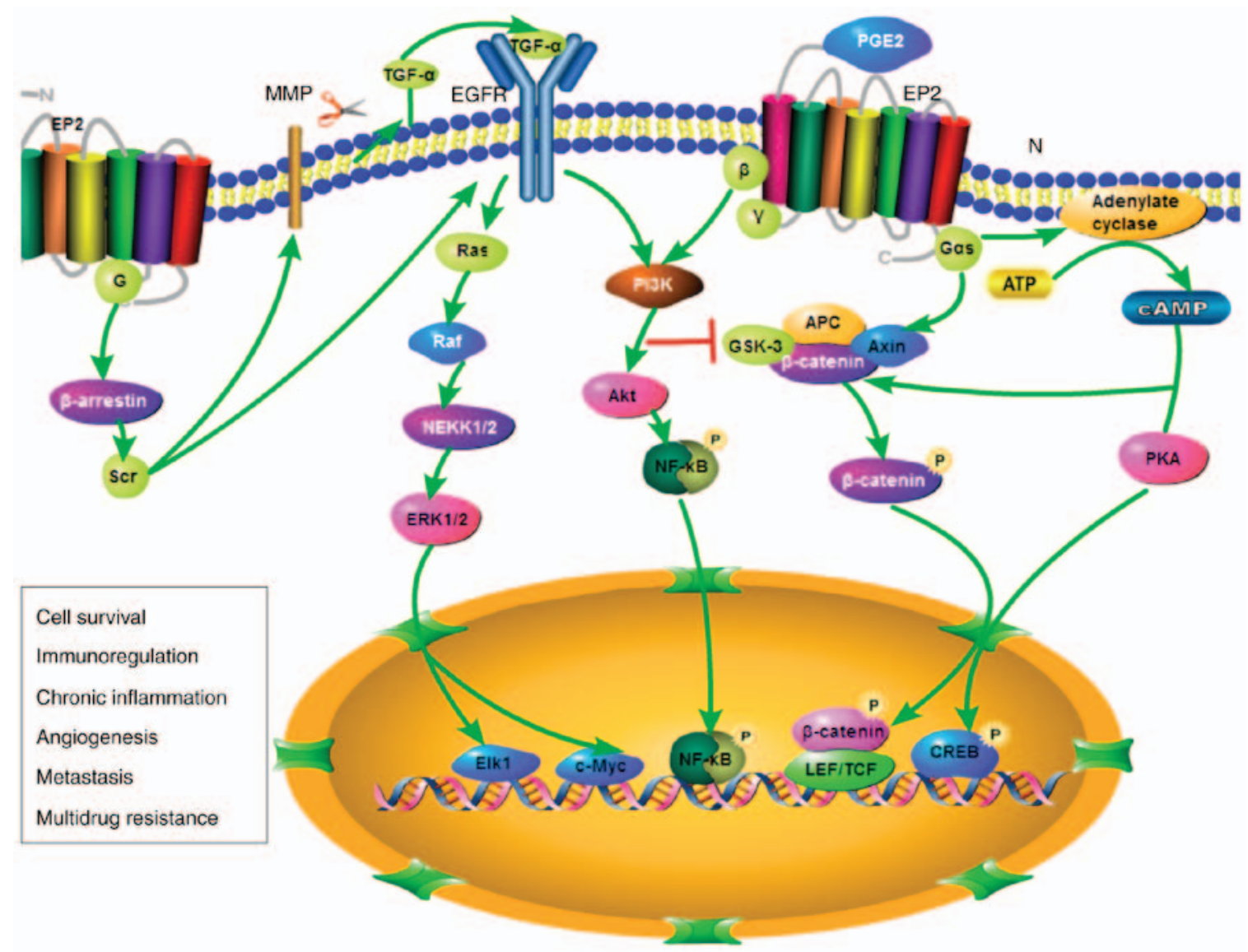

Figure 6. Signal transduction mediated by EP2. In response to prostaglandin E2 stimulation, EP2 receptor mediates second messenger signaling through the $\mathrm{EP} 2-\mathrm{G}_{\mathrm{s}}$-axin-pathway and induces crosstalk with other signaling pathways to conduct numerous actions involved in cell survival, immunoregulation, chronic inflammation, angiogenesis, metastasis and multidrug resistance. EP, prostaglandin E2 receptor 2 subtype.

\section{Development of agonists, antagonists and targeted drugs for EP2}

The following standard prostaglandins can activate EP2, with a binding efficacy in the following order: PGE2 $>$ PGF2 $\alpha \geq$ PGI2>PGD2 (100). Receptor-binding affinity, expressed as the dissociation constant, is $\sim 13 \mathrm{nM}$ for PGE2 and $\sim 10 \mathrm{nM}$ for PGE1 for the human receptor, and $\sim 12 \mathrm{nM}$ for PGE2 for the mouse receptor (101).

Apart from endogenous prostaglandins, three classes of EP2 receptor agonists have been discussed. These agonists are useful for the study of the function of EP2 and may be clinically useful for the treatment of certain diseases, including glaucoma and inflammatory bowel disease, and for the stimulation of hair growth and the stimulation of hair to terminal hair transformation (102). The first one comprises ligands that are similar in structure to the endogenous ligand PGE2. In order to enhance potency and selectivity, the $\omega$-lipophilic chain has been modified, such as in the free acid metabolite of butaprost (102). However, in binding studies, the selectivity of butaprost for EP2 was only 18-fold of that for EP3 (103). Due to its chemical instability and weak potency relative to PGE2, ONO-AE1-259-01 ( $\mathrm{R}=$ allyl; $\mathrm{K}_{\mathrm{i}}=1.7 \mathrm{nM}, \mathrm{EC}_{50}=1.8 \mathrm{nM}$ ) has been developed, introducing a $9 \beta$-chloro group in the place of the C9-carbonyl moiety (104). The second class of agonists is a series of pyridyl-sulfonamide derivatives, such as PF-04217329 and CP-544326. The latter class is a set of pyridylaminoacetic acids, one of which is TG3-95-1, which is only weakly active $\left(\mathrm{EC}_{50}=7.8 \mathrm{mM}\right)$, but it may be worth mentioning as it represents the only identified EP2-selective class of allosteric potentiators. Apart from the natural agonist of EP2, a number of PGE2 agonists, such as butaprost, CAY10399 and ONO-AE1-259-01, and compounds with a non-prostanoid structure, such as CP-533536, can also activate EP2 (105).

Due to the lack of selective antagonists for EP2, the majority if studies focusing on the function of EP receptors in cancer have been based upon genetic deletion and knockout studies (106). Although the genetic deletion of prostanoid receptors is very useful, it is overcomplicated and may result in hypertension. Numerous small-molecule ligands targeted to EP2 have been developed to complement this strategy $(107,108)$.

The non-selective EP receptor antagonist AH6809 has been widely applied to explore the roles of PGE2/EP2 signaling under normal and pathological conditions (109). Although AH6809 acts as an antagonist of EP2, it may also serve as an antagonist of EP1 and DP1 (110); it is neither selective nor potent, and is therefore unsuitable for in vivo studies (111). However, it has been demonstrated that allosteric potentiators and selective antagonists of the EP2 receptor with non-prostanoid structure can explain the physiological functions of prostaglandin receptors (112). These EP2 small-molecule modulators, such as PF-04418948 $\left(\mathrm{K}_{\mathrm{i}}=16 \mathrm{nM}\right)$, TG4-155 ( $\left.\mathrm{K}_{\mathrm{i}}=9.9 \mathrm{nM}\right)$, TG8-4 and TG6-129, which have been used for studies in animal models of human diseases, enable differentiation of EP2 from other 

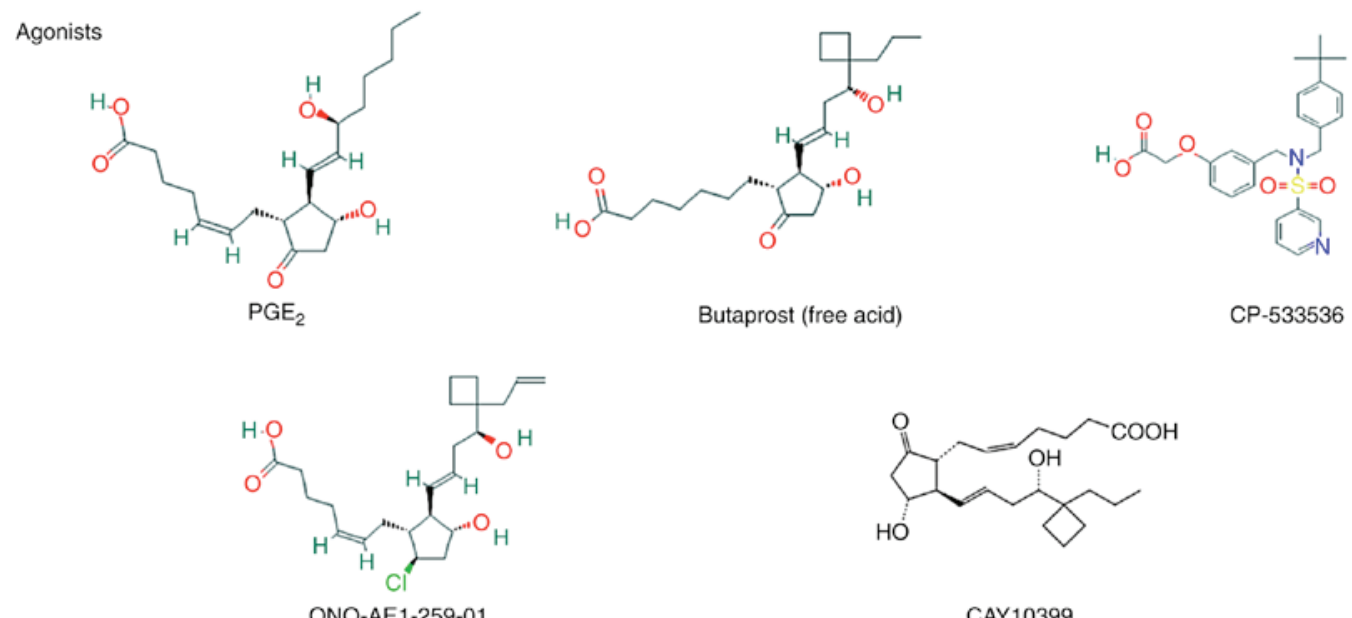

CAY10399
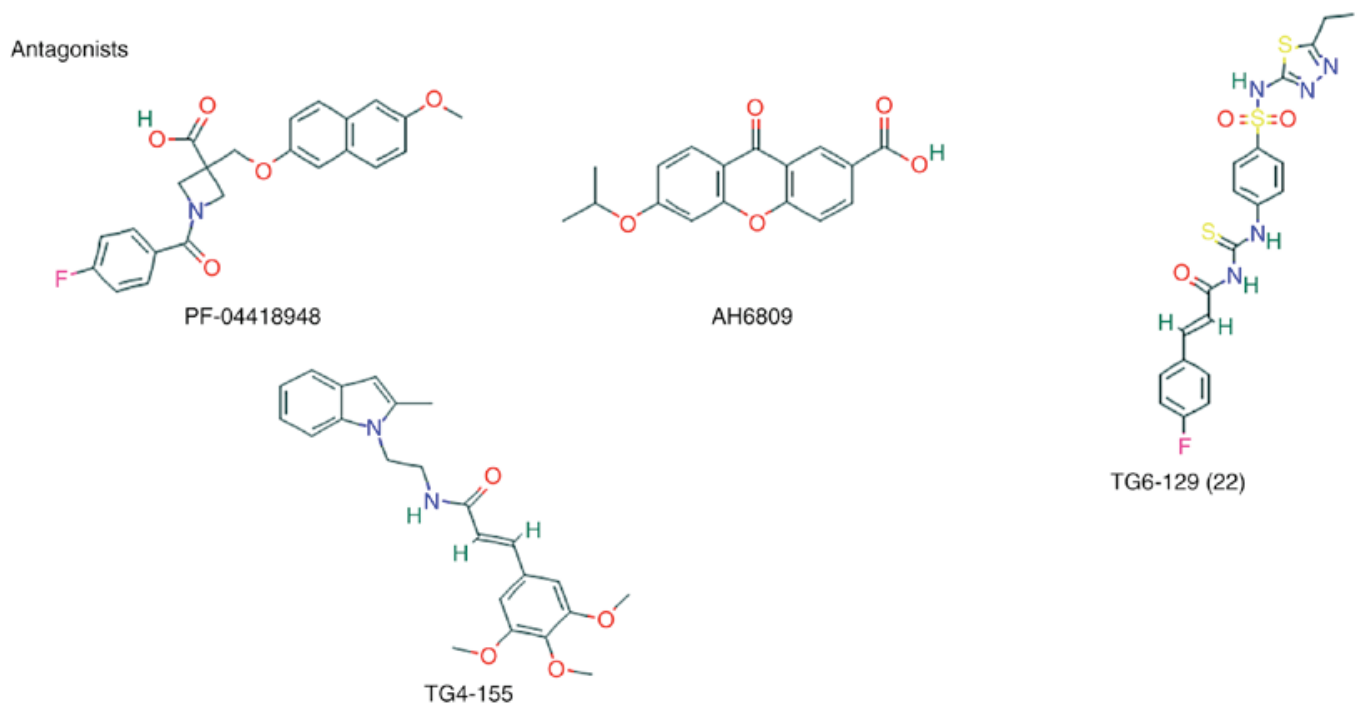

TG6-129 (22)

Figure 7. Agonists and antagonists of prostaglandin E2 receptor 2 subtype.

prostanoid receptors (113). The increasing number of tools for studying EP2 may enable a better understanding of the role of this receptor under normal and pathological conditions (Fig. 7).

\section{Conclusions and prospects}

COX is a rate-limiting enzyme in biosynthetic pathways. Although drugs targeting COX enzymes, such as NSAIDs or specific COX-2 inhibitors, have been clinically used to treat various diseases, they may be associated with numerous side effects, including gastric ulcers and myocardial infarction. Therefore, these adverse reactions limit the use of such drugs. In the COX-2 downstream signaling pathway, EP2 is an important mediator in several physiological and pathological events. It has been demonstrated that EP2 can interact with G proteins through the formation of EP2 and $\beta$-arrestin ( $\beta$-inhibitory proteins act as modulators), and signaling can be switched to the $\mathrm{G}$ protein-independent pathway. The update on selective EP2 antagonists may be helpful in explaining the functions of EP2 to supplement genetic knockout studies (114). Furthermore, nano-drug delivery technology and EP2-targeted drugs may be applied in the treatment of cancer. By establishing drug-loaded nanoparticles targeting EP2, a novel nano-drug delivery system may be established to increase drug targeting. In conclusion, studying EP2 may help elucidate the mechanisms underlying cancer invasion and metastasis, angiogenesis, chronic inflammation, tumor immunity and apoptosis, and may aid the development of novel molecular targeting therapeutic strategies.

\section{Acknowledgements}

The Genotype-Tissue Expression (GTEx) Project was supported by the Common Fund of the Office of the Director of the National Institutes of Health, and by NCI, NHGRI, NHLBI, NIDA, NIMH, and NINDS. The data used for the analyses described in this manuscript were obtained from: [https://www.gtexportal. org/home/] the GTEx Portal on 04/22/17 and dbGaP accession number phs000424.v7.p2 on 04/22/2017. The RNA-Seq datasets used by GEPIA are based on the UCSC Xena project (http://xena. ucsc.edu), which are computed by a standard pipeline.

\section{Funding}

This study was supported by the International Cooperation Key Project of the National Natural Science Foundation of China (grant no. 81520108031 to Q.L.), the Science 
Foundation of Shanghai Committee of Science Project (grant no. 14430722900), and the Program for Outstanding Medical Academic Leader and Shanghai Academic Research Leader (grant no. 16XD1403600).

\section{Availability of data and materials}

The datasets used and/or analyzed during the current study are available from the corresponding author on reasonable request.

\section{Authors' contributions}

XS compiled the information and wrote the review, QL revised the manuscript critically for important intellectual content.

\section{Ethics approval and consent to participate}

Not applicable.

\section{Patient consent for publication}

Not applicable.

\section{Competing interests}

The authors declare that they have no competing interests.

\section{References}

1. Cui FB, Huang DF, Zhang FL, Gao EY, Zhang Y, Cao YM, Ding S, Wang Y, Cao QS and Cao XM: Investigation on the regulatory effect of PGE2 on ESCC cells through the trans-activation of EGFR by EP2 and the relevant mechanism. Eur Rev Med Pharmacol Sci 21: 5668-5676, 2017.

2. Asting AG, Iresjö BM, Nilsberth C, Smedh U and Lundholm K: Host knockout of E-prostanoid 2 receptors reduces tumor growth and causes major alterations of gene expression in prostaglandin E2-producing tumors. Oncol Lett 13: 476-482, 2017.

3. Flórez-Grau G, Cabezón R, Borgman KJE, España C, Lozano JJ, Garcia-Parajo MF and Benitez-Ribas D: Up-regulation of EP2 and EP3 receptors in human tolerogenic dendritic cells boosts the immunosuppressive activity of PGE2. J Leukoc Biol 102: 881-895, 2017.

4. Maric J, Ravindran A, Mazzurana L, Björklund ÅK, Van Acker A, Rao A, Friberg D, Dahlén SE, Heinemann A, Konya V and Mjösberg J: Prostaglandin E2 suppresses human group 2 innate lymphoid cell function. J Allergy Clin Immunol 141: 1761-1773, 2018.

5. Hsu HH, Lin YM, Shen CY, Shibu MA, Li SY, Chang SH, Lin CC, Chen RJ, Viswanadha VP, Shih HN and Huang CY: Prostaglandin E2-induced COX-2 expressions via EP2 and EP4 signaling pathways in human LoVo colon cancer cells. Int J Mol Sci 18: pii: E1132, 2017.

6. Gong WH, Zhao N, Zhang ZM, Zhang YX, Yan L and Li JB: The inhibitory effect of resveratrol on COX-2 expression in human colorectal cancer: A promising therapeutic strategy. Eur Rev Med Pharmacol Sci 21: 1136-1143, 2017.

7. Wehbi VL and Taskén K: Molecular mechanisms for cAMP-mediated immunoregulation in t cells-role of anchored protein kinase a signaling units. Front Immunol 7: 222, 2016.

8. Shishikura K, Horiuchi T, Sakata N, Trinh DA, Shirakawa R, Kimura T, Asada Y and Horiuchi H: Prostaglandin E2 inhibits neutrophil extracellular trap formation through production of cyclic AMP. Br J Pharmacol 173: 319-331, 2016.

9. Lee SE,Lim C,Kim H and Cho S: A study of the anti-inflammatory effects of the ethyl acetate fraction of the methanol extract of forsythiae fructus. Afr J Tradit Complement Altern Med 13: 102-113, 2016
10. Xu L, Stevens J, Hilton MB, Seaman S, Conrads TP, Veenstra TD, Logsdon D, Morris H, Swing DA, Patel NL, et al: COX-2 inhibition potentiates antiangiogenic cancer therapy and prevents metastasis in preclinical models. Sci Transl Med 6: 242ra284, 2014.

11. Al-Taei S, Salimu J, Spary LK, Clayton A, Lester JF and Tabi Z: Prostaglandin $\mathrm{E}_{2}$-mediated adenosinergic effects on CD14 ${ }^{+}$cells: Self-amplifying immunosuppression in cancer. Oncoimmunology 6: e1268308, 2016.

12. Fan Y, Wang Y and Wang K: Prostaglandin E2 stimulates normal bronchial epithelial cell growth through induction of c-Jun and PDK1, a kinase implicated in oncogenesis. Respir Res 16: 149, 2015.

13. O'Callaghan G and Houston A: Prostaglandin E2 and the EP receptors in malignancy: Possible therapeutic targets? Br J Pharmacol 172: 5239-5250, 2015.

14. Kuo KT, Wang HW, Chou TY, Hsu WH, Hsu HS, Lin CH and Wang LS: Prognostic role of PGE2 receptor EP2 in esophageal squamous cell carcinoma. Ann Surg Oncol 16: 352-360, 2009.

15. Edwards TL, Shrubsole MJ, Cai Q, Li G, Dai Q, Rex DK, Ulbright TM, Fu Z, Murff HJ, Smalley W, et al: A study of prostaglandin pathway genes and interactions with current nonsteroidal anti-inflammatory drug use in colorectal adenoma. Cancer Prev Res (Phila) 5: 855-863, 2012.

16. Tian M and Schiemann WP: PGE2 receptor EP2 mediates the antagonistic effect of COX-2 on TGF-beta signaling during mammary tumorigenesis. FASEB J 24: 1105-1116, 2010.

17. Yu L, Wu WK, Li ZJ, Li HT, Wu YC and Cho CH: Prostaglandin $\mathrm{E}(2)$ promotes cell proliferation via protein kinase C/extracellular signal regulated kinase pathway-dependent induction of c-Myc expression in human esophageal squamous cell carcinoma cells. Int J Cancer 125: 2540-2546, 2009.

18. Trzaskowski B, Latek D, Yuan S, Ghoshdastider U, Debinski A and Filipek S: Action of molecular switches in GPCRs - theoretical and experimental studies. Curr Med Chem 19: 1090-1109, 2012.

19. King N, Hittinger CT and Carroll SB: Evolution of key cell signaling and adhesion protein families predates animal origins. Science 301: 361-363, 2003.

20. Liu X, Ahn S, Kahsai AW, Meng KC, Latorraca NR, Pani B, Venkatakrishnan AJ, Masoudi A, Weis WI, Dror RO, et al: Mechanism of intracellular allosteric $\beta 2 \mathrm{AR}$ antagonist revealed by X-ray crystal structure. Nature 548: 480-484, 2017.

21. Engelhardt S and Rochais F: G proteins: More than transducers of receptor-generated signals? Circ Res 100: 1109-1111, 2007.

22. Gilman AG: G proteins: Transducers of receptor-generated signals. Annu Rev Biochem 56: 615-649, 1987.

23. Kinoshita A, Higashino M, Yoshida K, Aratani Y, Kakuuchi A, Hanada K, Takeda H, Naganawa A, Matsuya $\mathrm{H}$ and Ohmoto K: Synthesis and evaluation of a potent, well-balanced EP2/EP3 dual agonist. Bioorg Med Chem 26: 200-214, 2018.

24. Wang J, Zhang L, Kang D, Yang D and Tang Y: Activation of PGE2/EP2 and PGE2/EP4 signaling pathways positively regulate the level of PD-1 in infiltrating CD8 ${ }^{+} \mathrm{T}$ cells in patients with lung cancer. Oncol Lett 15: 552-558, 2018.

25. Ota H, Katanosaka K, Murase S, Furuyashiki T, Narumiya S and Mizumura K: EP2 receptor plays pivotal roles in generating mechanical hyperalgesia after lengthening contractions. Scand J Med Sci Sports 28: 826-833, 2018.

26. Wang S, Xie L, Zhang Y, Xu P and Liu A: Expression of prostaglandin $\mathrm{E}_{2}$ receptors in acquired middle ear cholesteatoma. Clin Exp Otorhinolaryngol 11: 17-22, 2018.

27. Dinç E, Dursun Ö, Yilmaz B, Vatansever M, Sari AA, Yıldırım Ö and Adıgüzel U: Expression of prostaglandin E2 receptor subtypes in human pterygium and normal conjunctiva: Immunohistochemical study. Int Ophthalmol, Jul 10, 2017 (Epub ahead of print).

28. Yu Y and Chadee K: Prostaglandin E2 stimulates IL-8 gene expression in human colonic epithelial cells by a posttranscriptional mechanism. J Immunol 161: 3746-3752, 1998.

29. Nakayama T, Mutsuga N, Yao L and Tosato G: Prostaglandin E2 promotes degranulation-independent release of MCP-1 from mast cells. J Leukoc Biol 79: 95-104, 2006.

30. Weller CL, Collington SJ, Hartnell A, Conroy DM, Kaise T, Barker JE, Wilson MS, Taylor GW, Jose PJ and Williams TJ: Chemotactic action of prostaglandin E2 on mouse mast cells acting via the PGE2 receptor 3. Proc Natl Acad Sci USA 104: 11712-11717, 2007.

31. Margeta-Mitrovic M, Jan YN and Jan LY: A trafficking checkpoint controls GABA(B) receptor heterodimerization. Neuron 27: 97-106, 2000 
32. Malty RH, Hudmon A, Fehrenbacher JC and Vasko MR: Long-term exposure to PGE2 causes homologous desensitization of receptor-mediated activation of protein kinase $\mathrm{A}$ J Neuroinflammation 13: 181, 2016.

33. Shibuya I, Setiadji SV, Ibrahim N, Harayama N, Maruyama T, Ueta $\mathrm{Y}$ and Yamashita $\mathrm{H}$ : Involvement of postsynaptic EP4 and presynaptic EP3 receptors in actions of prostaglandin E2 in rat supraoptic neurones. J Neuroendocrinol 14: 64-72, 2002.

34. Su Y, Jackson EK and Gorelik E: Receptor desensitization and blockade of the suppressive effects of prostaglandin $E(2)$ and adenosine on the cytotoxic activity of human melanoma-infiltrating T lymphocytes. Cancer Immunol Immunother 60: 111-122, 2011

35. Aoki $T$ and Narumiya $S$ : Prostaglandin $E_{2}-E P 2$ signaling as a node of chronic inflammation in the colon tumor microenvironment. Inflamm Regen 37: 4, 2017.

36. Salinas-Parra N, Reyes-Martinez C, Prieto MC and Gonzalez AA Prostaglandin E2 induces prorenin-dependent activation of (Pro) renin receptor and upregulation of cyclooxygenase-2 in collecting duct cells. Am J Med Sci 354: 310-318, 2017.

37. Byun JY, Youn YS, Lee YJ, Choi YH, Woo SY and Kang JL: Interaction of apoptotic cells with macrophages upregulates COX-2/PGE2 and HGF expression via a positive feedback loop. Mediators Inflamm 2014: 463524, 2014.

38. Baba Y, Nosho K, Shima K, Goessling W, Chan AT, Ng K, Chan JA, Giovannucci EL, Fuchs CS and Ogino S: PTGER2 overexpression in colorectal cancer is associated with microsatellite instability, independent of $\mathrm{CpG}$ island methylator phenotype. Cancer Epidemiol Biomarkers Prev 19: 822-831, 2010.

39. Castellone MD, Teramoto H, Williams BO, Druey KM and Gutkind JS: Prostaglandin E2 promotes colon cancer cell growth through a Gs-axin-beta-catenin signaling axis. Science 310 : 1504-1510, 2005.

40. Hsu HH, Chen MC, Day CH, Lin YM, Li SY, Tu CC, Padma VV, Shih HN, Kuo WW and Huang CY: Thymoquinone suppresses migration of LoVo human colon cancer cells by reducing prostaglandin E2 induced COX-2 activation. World J Gastroenterol 23 : 1171-1179, 2017.

41. Lian S, Xia Y, Ung TT, Khoi PN, Yoon HJ, Lee SG, Kim KK and Jung YD: Prostaglandin $\mathrm{E}_{2}$ stimulates urokinase-type plasminogen activator receptor via EP2 receptor-dependent signaling pathways in human AGS gastric cancer cells. Mol Carcinog 56: 664-680, 2017

42. Merz C, von Mässenhausen A, Queisser A, Vogel W, Andrén O, Kirfel J, Duensing S, Perner S and Nowak M: IL-6 overexpression in ERG-positive prostate cancer is mediated by prostaglandin receptor EP2. Am J Pathol 186: 974-984, 2016.

43. Zang S, Ma X, Wu Y, Liu W, Cheng H, Li J, Liu J and Huang A: PGE2 synthesis and signaling in malignant transformation and progression of human hepatocellular carcinoma. Hum Pathol 63 120-127, 2017

44. Koh SJ, Kim JM, Kim IK, Ko SH and Kim JS: Anti-inflammatory mechanism of metformin and its effects in intestinal inflammation and colitis-associated colon cancer. J Gastroenterol Hepatol 29: 502-510, 2014.

45. Bonfill-Teixidor E, Otxoa-de-Amezaga A, Font-Nieves M, Sans-Fons MG and Planas AM: Differential expression of E-type prostanoid receptors 2 and 4 in microglia stimulated with lipopolysaccharide. J Neuroinflammation 14: 3, 2017.

46. Huynh K: Inflammation: Targeting inflammatory pathways to treat atherosclerosis and cancer. Nat Rev Cardiol 14: 629, 2017

47. Liu Y, Fang S, Li X, Feng J, Du J, Guo L, Su Y, Zhou J, Ding G, Bai Y, et al: Aspirin inhibits LPS-induced macrophage activation via the NF-кB pathway. Sci Rep 7: 11549, 2017.

48. Kang X, Qiu J, Li Q, Bell KA, Du Y, Jung DW, Lee JY, Hao J and Jiang J: Cyclooxygenase-2 contributes to oxidopamine-mediated neuronal inflammation and injury via the prostaglandin E2 receptor EP2 subtype. Sci Rep 7: 9459, 2017.

49. Gill SK, Yao Y, Kay LJ, Bewley MA, Marriott HM and Peachell PT: The anti-inflammatory effects of PGE2 on human lung macrophages are mediated by the EP4 receptor. Br J Pharmacol 173: 3099-3109, 2016.

50. Kawahara K, Hohjoh H, Inazumi T, Tsuchiya S and Sugimoto Y: Prostaglandin E2-induced inflammation: Relevance of prostaglandin E receptors. Biochim Biophys Acta 1851: 414-421, 2015.

51. Jiang J, Quan Y, Ganesh T, Pouliot WA, Dudek FE and Dingledine R: Inhibition of the prostaglandin receptor EP2 following status epilepticus reduces delayed mortality and brain inflammation. Proc Natl Acad Sci USA 110: 3591-3596, 2013.
52. Hooper KM, Yen JH, Kong W, Rahbari KM, Kuo PC, Gamero AM and Ganea D: Prostaglandin E2 Inhibition of IL-27 Production in Murine Dendritic Cells: A novel mechanism that involves IRF1. J Immunol 198: 1521-1530, 2017.

53. Li S, Xu X, Jiang M, Bi Y, Xu J and Han M: Lipopolysaccharide induces inflammation and facilitates lung metastasis in a breast cancer model via the prostaglandin E2-EP2 pathway. Mol Med Rep 11: 4454-4462, 2015.

54. Li X, Su Y, Hua X, Xie C, Liu J, Huang Y, Zhou L, Zhang M, Li X and Gao Z: Levels of hepatic Th17 cells and regulatory T cells upregulated by hepatic stellate cells in advanced HBV-related liver fibrosis. J Transl Med 15: 75, 2017.

55. Fennekohl A, Lucas M and Püschel GP: Induction by interleukin 6 of $\mathrm{G}(\mathrm{s})$-coupled prostaglandin $\mathrm{E}(2)$ receptors in rat hepatocytes mediating a prostaglandin $\mathrm{E}(2)$-dependent inhibition of the hepatocyte's acute phase response. Hepatology 31 $1128-1134,2000$

56. Kabashima K, Nagamachi M, Honda T, Nishigori C, Miyachi Y, Tokura Y and Narumiya S: Prostaglandin E2 is required for ultraviolet $\mathrm{B}$-induced skin inflammation via EP2 and EP4 receptors. Lab Invest 87: 49-55, 2007.

57. Prasad R and Katiyar SK: Ultraviolet radiation-induced inflammation activates $\beta$-catenin signaling in mouse skin and skin tumors. Int J Oncol 44: 1199-1206, 2014.

58. Prasad R and Katiyar SK: Prostaglandin E2 Promotes UV radiation-induced immune suppression through DNA hypermethylation. Neoplasia 15: 795-804, 2013.

59. Ma X, Aoki T, Tsuruyama T and Narumiya S: Definition of prostaglandin E2-EP2 signals in the colon tumor microenvironment that amplify inflammation and tumor growth. Cancer Res 75: 2822-2832, 2015.

60. Shehzad A, U1 Islam S, Lee J and Lee YS: Prostaglandin E2 reverses curcumin-induced inhibition of survival signal pathways in human colorectal carcinoma (HCT-15) cell lines. Mol Cells 37: 899-906, 2014.

61. Wang D, Huang S, Yuan X, Liang J, Xu R, Yao G, Feng X and Sun L: The regulation of the Treg/Th17 balance by mesenchymal stem cells in human systemic lupus erythematosus. Cell Mol Immunol 14: 423-431, 2017.

62. Lejeune M, Moreau F and Chadee K: Loss of EP2 receptor subtype in colonic cells compromise epithelial barrier integrity by altering claudin-4. PLos One 9: e113270, 2014.

63. Trésfier A, Musnier A, Landomiel F, Bourquard T, Boulo T, Ayoub MA, León K, Bruneau G, Chevalier M, Durand G, et al: $\mathrm{G}$ protein-dependent signaling triggers a $\beta$-arrestin-scaffolded p70S6K/ rpS6 module that controls 5'TOP mRNA translation. FASEB J 32: 1154-1169, 2018.

64. Kaul V, Bhattacharya D, Singh Y, Van Kaer L, Peters-Golden M, Bishai WR and Das G: An important role of prostanoid receptor EP2 in host resistance to Mycobacterium tuberculosis infection in mice. J Infect Dis 206: 1816-1825, 2012.

65. Qian X, Zhang J and Liu J: Tumor-secreted PGE2 inhibits CCL5 production in activated macrophages through cAMP/PKA signaling pathway. J Biol Chem 286: 2111-2120, 2011.

66. Leander R and Friedman A: Modulation of the cAMP response by Gai and G $\beta \gamma$ : A computational study of $G$ protein signaling in immune cells. Bull Math Biol 76: 1352-1375, 2014.

67. Sreeramkumar V, Hons M, Punzón C, Stein JV, Sancho D, Fresno $\mathrm{M}$ and Cuesta $\mathrm{N}$ : Efficient T-cell priming and activation requires signaling through prostaglandin E2 (EP) receptors. Immunol Cell Biol 94: 39-51, 2016.

68. Mao Y, Sarhan D, Steven A, Seliger B, Kiessling R and Lundqvist A: Inhibition of tumor-derived prostaglandin-e2 blocks the induction of myeloid-derived suppressor cells and recovers natural killer cell activity. Clin Cancer Res 20: 4096-4106, 2014.

69. Yang L, Yamagata N, Yadav R, Brandon S, Courtney RL, Morrow JD, Shyr Y, Boothby M, Joyce S, Carbone DP and Breyer RM: Cancer-associated immunodeficiency and dendritic cell abnormalities mediated by the prostaglandin EP2 receptor. J Clin Invest 111: 727-735, 2003.

70. Marin-Acevedo JA, Soyano AE, Dholaria B, Knutson KL and Lou Y: Cancer immunotherapy beyond immune checkpoint inhibitors. J Hematol Oncol 11: 8, 2018.

71. Fujimoto Y, Iwagaki H, Ozaki M, Ogino T, Murata H, Sun DS, Sadamori H, Takahashi HK, Tanaka N and Yagi T: Involvement of prostaglandin receptors (EPR2-4) in in vivo immunosuppression of PGE2 in rat skin transplant model. Int Immunopharmacol 5: 1131-1139, 2005. 
72. Bonanno A, Albano GD, Siena L, Montalbano AM Riccobono L, Anzalone G, Chiappara G, Gagliardo R, Profita M and Sala A: Prostaglandin $E_{2}$ possesses different potencies in inducing Vascular Endothelial Growth Factor and Interleukin-8 production in COPD human lung fibroblasts. Prostaglandins Leukot Essent Fatty Acids 106: 11-18, 2016.

73. Wiktorowska-Owczarek A and Owczarek J: The effect of hypoxia on PGE2-stimulated cAMP generation in HMEC-1. Cell Mol Biol Lett 20: 213-221, 2015.

74. Aoyagi T, Newstead MW, Zeng X, Nanjo Y, Peters-Golden M, Kaku M and Standiford TJ: Interleukin-36 $\gamma$ and IL-36 receptor signaling mediate impaired host immunity and lung injury in cytotoxic Pseudomonas aeruginosa pulmonary infection: Role of prostaglandin E2. PLos Pathog 13: e1006737, 2017.

75. Takahashi $\mathrm{T}$, Uehara $\mathrm{H}$ and Izumi $\mathrm{K}$ : Inhibitory effect of soluble EP2 receptor on ovarian tumor growth in nude mice and utility of TMPRSS4 as a combinatorial molecular target. Int J Oncol 43: 416-424, 2013

76. Cheng SY, Zhang H, Zhang M, Xia SK, Bai XM, Zhang L, Ma J, Rong R, Wang YP, Du MZ, et al: Prostaglandin $\mathrm{E}_{2}$ receptor EP2 mediates Snail expression in hepatocellular carcinoma cells. Oncol Rep 31: 2099-2106, 2014.

77. Sobhani N, Roviello G, Corona SP, Scaltriti M, Ianza A Bortul M, Zanconati $\mathrm{F}$ and Generali D: The prognostic value of PI3K mutational status in breast cancer: A meta-analysis. J Cell Biochem 119: 4287-4292, 2018.

78. Ma W and St-Jacques B: Signalling transduction events involved in agonist-induced PGE2/EP4 receptor externalization in cultured rat dorsal root ganglion neurons. Eur J Pain 22: 845-861, 2018.

79. Regan JW: EP2 and EP4 prostanoid receptor signaling. Life Sci 74: 143-153, 2003.

80. Allison SE, Petrovic N, Mackenzie PI and Murray M: Pro-migratory actions of the prostacyclin receptor in human breast cancer cells that over-express cyclooxygenase- 2 . Biochem Pharmacol 96: 306-314, 2015.

81. Cheuk IW, Shin VY, Siu MT, Tsang JY, Ho JC, Chen J, Tse GM Wang $X$ and Kwong A: Association of EP2 receptor and SLC19A3 in regulating breast cancer metastasis. Am J Cancer Res 5: 3389-3399, 2015.

82. Kim KM, Im AR, Kim SH, Hyun JW and Chae S: Timosaponin AIII inhibits melanoma cell migration by suppressing COX-2 and in vivo tumor metastasis. Cancer Sci 107: 181-188, 2016.

83. Rundhaug JE, Simper MS, Surh I and Fischer SM: The role of the EP receptors for prostaglandin E2 in skin and skin cancer. Cancer Metastasis Rev 30: 465-480, 2011.

84. Rundhaug JE and Fischer SM: Cyclo-oxygenase-2 plays a critical role in UV-induced skin carcinogenesis. Photochem Photobiol 84: 322-329, 2008

85. Singh T, Vaid M, Katiyar N, Sharma S and Katiyar SK: Berberine, an isoquinoline alkaloid, inhibits melanoma cancer cell migration by reducing the expressions of cyclooxygenase-2, prostaglandin $\mathrm{E}_{2}$ and prostaglandin $\mathrm{E}_{2}$ receptors Carcinogenesis 32: 86-92, 2011

86. Mochocki M, Morawski P, Kopta R, Brzezinska-Blaszczyk E, Stasikowska O, Lewy-Trenda I; Student Scientific Circle and Starska K: Expression of prostaglandin E2 prostanoid receptor EP2 and interleukin-1 $\beta$ in laryngeal carcinoma-preliminary study. Contemp Oncol (Pozn) 19: 113-119, 2015.

87. Cantaut-Belarif Y, Antri M, Pizzarelli R, Colasse S, Vaccari I, Soares S, Renner M, Dallel R, Triller A and Bessis A: Microglia control the glycinergic but not the GABAergic synapses via prostaglandin E2 in the spinal cord. J Cell Biol 216: 2979-2989, 2017

88.de Almeida VH, de Melo AC, Meira DD, Pires AC, Nogueira-Rodrigues A, Pimenta-Inada HK, Alves FG, Moralez G, Thiago LS, Ferreira CG and Sternberg C: Radiotherapy modulates expression of EGFR, ERCC1 and p53 in cervical cancer. Braz J Med Biol Res 51: e6822, 2017.

89. Ochoa MC, Minute L, López A4, Pérez-Ruiz E, Gomar C, Vasquez M, Inoges S, Etxeberria I, Rodriguez I, Garasa S, et al: Enhancement of antibody-dependent cellular cytotoxicity of cetuximab by a chimeric protein encompassing interleukin-15. Oncoimmunology 7: e1393597, 2017.

90. Chen A, Ali N, Boasberg P and Ho AS: Clinical remission of cutaneous squamous cell carcinoma of the auricle with cetuximab and nivolumab. J Clin Med 7: pii: E10, 2018.

91.Fernández-Martínez AB and Lucio-Cazaña J: Intracellular EP2 prostanoid receptor promotes cancer-related phenotypes in PC3 cells. Cell Mol Life Sci 72: 3355-3373, 2015.
92. López Bernal A, Rivera J, Europe-Finner GN, Phaneuf S and Asbóth G: Parturition: Activation of stimulatory pathways or loss of uterine quiescence? Adv Exp Med Biol 395: 435-451, 1995.

93. Brocard E, Oizel K, Lalier L, Pecqueur C, Paris F, Vallette FM and Oliver L: Radiation-induced PGE2 sustains human glioma cells growth and survival through EGF signaling. Oncotarget 6: 6840-6849, 2015

94. Schmidt A, Sinnett-Smith J, Young S, Chang HH, Hines OJ, Dawson DW, Rozengurt E and Eibl G: Direct growth-inhibitory effects of prostaglandin E2 in pancreatic cancer cells in vitro through an EP4/PKA-mediated mechanism. Surgery 161: 1570-1578, 2017.

95. Vaid M, Singh T, Prasad R, Kappes JC and Katiyar SK: Therapeutic intervention of proanthocyanidins on the migration capacity of melanoma cells is mediated through PGE2 receptors and $\beta$-catenin signaling molecules. Am J Cancer Res 5: 3325-3338, 2015.

96. Chang HH, Young SH, Sinnett-Smith J, Chou CE, Moro A, Hertzer KM, Hines OJ, Rozengurt E and Eibl G: Prostaglandin E2 activates the mTORC1 pathway through an EP4/cAMP/PKAand $\mathrm{EP} 1 / \mathrm{Ca} 2+-$ mediated mechanism in the human pancreatic carcinoma cell line PANC-1. Am J Physiol Cell Physiol 309: C639-C649, 2015

97. Chun KS, Lao HC, Trempus CS, Okada M and Langenbach R The prostaglandin receptor EP2 activates multiple signaling pathways and beta-arrestin1 complex formation during mouse skin papilloma development. Carcinogenesis 30: 1620-1627, 2009.

98. Shu J, Zhang F, Zhang L and Wei W: G protein coupled receptors signaling pathways implicate in inflammatory and immune response of rheumatoid arthritis. Inflamm Res 66: 379-387, 2017

99. Yun SP, Ryu JM, Jang MW and Han HJ: Interaction of profilinand F-actin via a $\beta$-arrestin-1/JNK signaling pathway involved in prostaglandin $\mathrm{E}(2)$-induced human mesenchymal stem cells migration and proliferation. J Cell Physiol 226: 559-571, 2011.

100. Narumiya S, Sugimoto Y and Ushikubi F: Prostanoid receptors: Structures, properties, and functions. Physiol Rev 79: 1193-1226, 1999.

101. Ganesh T: Prostanoid receptor EP2 as a therapeutic target. J Med Chem 57: 4454-4465, 2014

102. Tani K, Naganawa A, Ishida A, Egashira H, Sagawa K, Harada H, Ogawa M, Maruyama T, Ohuchida S, Nakai H, et al: Design and synthesis of a highly selective EP2-receptor agonist. Bioorg Med Chem Lett 11: 2025-2028, 2001.

103. Jadhav V, Jabre A, Lin SZ and Lee TJ: EP1- and EP3-receptors mediate prostaglandin E2-induced constriction of porcine large cerebral arteries. J Cereb Blood Flow Metab 24: 1305-1316, 2004

104. Tani K, Naganawa A, Ishida A, Sagawa K, Harada H, Ogawa M, Maruyama T, Ohuchida S, Nakai H, Kondo K and Toda M: Development of a highly selective EP2-receptor agonist. Part 1: Identification of 16-hydroxy-17, 17-trimethylene PGE2 derivatives. Bioorg Med Chem 10: 1093-1106, 2002

105. Markovič T, Jakopin Ž, Dolenc MS and Mlinarič-Raščan I: Structural features of subtype-selective EP receptor modulators. Drug Discov Today 22: 57-71, 2017.

106. Yeo HS, Shehzad A and Lee YS: Prostaglandin E2 blocks menadione-induced apoptosis through the Ras/Raf/Erk signaling pathway in promonocytic leukemia cell lines. Mol Cells 33: 371-378, 2012

107. Tanné B, Bernier S and Dumais N: CCR7 receptor expression in Mono-MAC-1 cells: modulation by liver $\mathrm{X}$ receptor $\alpha$ activation and prostaglandin E 2. Int J Inflam 2015: 201571, 2015.

108. Takahashi HK, Liu K, Wake H, Mori S, Zhang J, Liu R, Yoshino T and Nishibori M: Prostaglandin E2 inhibits advanced glycation end product-induced adhesion molecule expression, cytokine production, and lymphocyte proliferation in human peripheral blood mononuclear cells. J Pharmacol Exp Ther 331: 656-670, 2009.

109. Wang R, Zhang W, Dong Z, Qi Y, Hultström M, Zhou X and Lai EY: c-Jun N-terminal Kinase mediates prostaglandin-induced sympathoexcitation in rats with chronic heart failure by reducing GAD1 and GABRA1 expression. Acta Physiol (Oxf) 219: 494-509, 2017

110. Cameron KO, Lefker BA, Ke HZ, Li M,Zawistoski MP, Tjoa CM, Wright AS, DeNinno SL, Paralkar VM, Owen TA, et al: Discovery of CP-533536: An EP2 receptor selective prostaglandin E2 (PGE2) agonist that induces local bone formation. Bioorg Med Chem Lett 19: 2075-2078, 2009. 
111. Säfholm J, Dahlén SE and Adner M: Antagonising EP1 and EP2 receptors reveal that the TP receptor mediates a component of antigen-induced contraction of the guinea pig trachea. Eur J Pharmacol 718: 277-282, 2013.

112. Yan G, Wang Q, Shi H, Han Y, Ma G, Tang C and Gu Y: Regulation of rat intrapulmonary arterial tone by arachidonic acid and prostaglandin E2 during hypoxia. PLoS One 8: e73839, 2013.

113. Kay LJ, Gilbert M, Pullen N, Skerratt S, Farrington J, Seward EP and Peachell PT: Characterization of the EP receptor subtype that mediates the inhibitory effects of prostaglandin E2 on IgE-dependent secretion from human lung mast cells. Clin Exp Allergy 43: 741-751, 2013.

114. af Forselles KJ, Root J, Clarke T, Davey D, Aughton K, Dack K and Pullen N: In vitro and in vivo characterization of PF-04418948, a novel, potent and selective prostaglandin EP2 receptor antagonist. Br J Pharmacol 164: 1847-1856, 2011.

115. Tang Z. Li C, Kang B, Gao G, Li C and Zhang Z. GEPIA: A web server for cancer and normal gene expression profiling and interactive analyses. Nucleic Acids Res 45 (W1): W98-W102, 2017. 